\title{
Metode Think-Pair-Share Dengan Analisis Artikel Untuk Meningkatkan Keterampilan Berpikir Tingkat Tinggi Mahasiswa
}

\author{
${ }^{1}$ Hikmawati, ${ }^{2}$ Haerunisyah Sahidu, ${ }^{3}$ Syahrial Ayub \\ ${ }^{1,2,3}$ Prodi Pendidikan Fisika, Jurusan Pendidikan MIPA, FKIP, Universitas Mataram, Jln. \\ Majapahit No.62, Mataram, NTB, 83125. \\ Email Korespondensi: hikmawati@unram.ac.id
}

\begin{tabular}{|c|c|}
\hline Article Info & \\
\hline $\begin{array}{l}\text { Article History } \\
\text { Received: } 18 \text { April } 2021 \\
\text { Revised: } 11 \text { Mei } 2021 \\
\text { Published: } 30 \text { June } 2021\end{array}$ & \multirow{2}{*}{$\begin{array}{l}\text { Think-Pair-Share Method With Article Analysis To Improve Students' } \\
\text { Higher Order Thinking Skills. The purpose of this study was to describe the } \\
\text { application of the think-pair-share method with article analysis to improve } \\
\text { students' higher order thinking skills. This type of research is pre-experimental } \\
\text { with research subjects, namely students who take the Physics Learning } \\
\text { Strategy course, academic year 2020/2021, at one of the universities in } \\
\text { Mataram, totaling } 27 \text { people. The research design used was One Group Pre- } \\
\text { test and Post-test Design. The instrument used in this study was a test of higher } \\
\text { order thinking skills. The level of higher order thinking skills of students is } \\
\text { calculated as a percentage, with } 5 \text { categories. The increase in score is } \\
\text { calculated using N-gain, with } 3 \text { criteria. The results showed that the level of } \\
\text { high-order thinking skills of students at the pre-test was } 49 \text { with a very low } \\
\text { category, while at the time of the post-test it was } 83 \text { in the good category. The } \\
\text { N-gain score is } 68 \text { with moderate criteria. Thus, the application of the think- } \\
\text { pair-share method with article analysis can improve students' higher-order } \\
\text { thinking skills in the Physics Learning Strategy course. }\end{array}$} \\
\hline $\begin{array}{l}\text { Keywords } \\
\text { Think-Pair-Share } \\
\text { higher-order } \\
\text { skills }\end{array}$ & \\
\hline Informa & Abstrak \\
\hline $\begin{array}{l}\text { Sejarah Artikel } \\
\text { Diterima: } 18 \text { April } 2021 \\
\text { Direvisi: } 11 \text { Mei } 2021 \\
\text { Dipublikasi: } 30 \text { Juni } 2021\end{array}$ & \multirow{2}{*}{$\begin{array}{l}\text { Tujuan penelitian ini adalah mendeskripsikan penerapan metode think-pair- } \\
\text { share dengan analisis artikel untuk meningkatkan keterampilan berpikir tingkat } \\
\text { tinggi mahasiswa. Jenis penelitian ini adalah pra-eksperimental dengan subjek } \\
\text { penelitian yaitu mahasiswa yang mengikuti mata kuliah Strategi Pembelajaran } \\
\text { Fisika, tahun akademik } 2020 / 2021 \text {, pada salah satu Universitas di Mataram, } \\
\text { sejumlah } 27 \text { orang. Desain penelitian yang digunakan adalah One Group Pre- } \\
\text { test dan Post-test Design. Instrumen yang digunakan dalam penelitian ini } \\
\text { adalah tes keterampilan berpikir tingkat tinggi. Tingkat keterampilan berpikir } \\
\text { tingkat tinggi mahasiswa dihitung dalam bentuk persentase, dengan } 5 \text { kategori. } \\
\text { Peningkatan skor dihitung menggunakan N-gain, dengan } 3 \text { kriteria. Hasil } \\
\text { penelitian menunjukkan bahwa tingkat keterampilan berpikir tingkat tinggi } \\
\text { mahasiswa pada saat pre-test sebesar } 49 \text { dengan kategori kurang sekali, } \\
\text { sedangkan pada saat post-test sebesar } 83 \text { dengan kategori baik. Skor N-gain } \\
\text { sebesar } 68 \text { dengan kriteria sedang. Dengan demikian, penerapan metode think- } \\
\text { pair-share dengan analisis artikel dapat meningkatkan keterampilan berpikir } \\
\text { tingkat tinggi mahasiswa pada mata kuliah Strategi Pembelajaran Fisika. }\end{array}$} \\
\hline $\begin{array}{l}\text { Kata kunci } \\
\text { Berpikir-Berpasan } \\
\text { Berbagi; } \\
\text { Keterampilan } \\
\text { tingkat tinggi }\end{array}$ & \\
\hline
\end{tabular}

Sitasi: Hikmawati, H., Sahidu H., \& Ayub, S. (2021). Metode Think-Pair-Share dengan Analisis Artikel untuk Meningkatkan Keterampilan Berpikir Tingkat Tinggi Mahasiswa. Kappa Journal, 5(1), 20-30.

\section{PENDAHULUAN}

Beberapa permasalahan yang terdapat dalam pembelajaran di kelas adalah siswa kurang aktif dalam proses pembelajaran di kelas seperti bertanya dan menjawab pertanyaan. Selain itu ketika guru mengajak siswa untuk berdiskusi, siswa kurang merespon pertanyaan dari guru dan siswa cenderung diam pada saat guru memberikan pertanyaan. Dari permasalahan tersebut diketahui kemampuan berpikir kritis siswa rendah. Metode think-pair-share menjadi 
salah satu cara yang efektif untuk membuat variasi suasana pola diskusi di dalam kelas yang membutuhkan pengaturan untuk mengendalikan kelas secara keseluruhan dapat memberi siswa waktu yang lebih banyak untuk berfikir, untuk merespon dan saling membantu (Nikmah, 2018).

Penerapan model pembelajaran kooperatif dengan metode think-pair-share dapat dilakukan dengan langkah-langkah yaitu melatih siswa untuk berpikir kritis secara mandiri (think), berpikir kritis dalam kelompok kecil dengan mendiskusikan dan saling mengoreksi hasil pekerjaan bersama pasangan (pair), serta dalam kelompok besar dengan mendiskusikan dan saling mengoreksi hasil pekerjaan kelompok yang mempresentasikan hasil diskusinya dalam berpasangan (share). Kemampuan berpikir kritis siswa yang dapat ditingkatkan melalui metode think-pair-share bisa dilihat dari beberapa indikator yaitu: 1) menganalisis dan memfokuskan pertanyaan, 2) menjawab pertanyaan tentang suatu penjelasan dan tantangan, 3) mengidentifikasi asumsi, 4) mempertimbangkan nilai keputusan (Astriani, 2017).

Menurut Purwantika, dkk (2020), penerapan metode think-pair-share pada pertemuan pertama, peserta didik dipimpin oleh ketua kelas untuk berdoa terlebih dahulu, setelah itu guru membuka kegiatan pembelajaran dengan mengucapkan salam, mengecek kehadiran peserta didik, dan memulai proses pembelajaran di kelas dengan menggunakan lembar kerja peserta didik (LKPD) berbasis saintifik sebagai bahan pelajaran. Dalam penyelesaian LKPD, peserta didik melalui tiga tahap yaitu think (Berpikir), pair (Berpasangan) dan share (Berbagi). Pada tahap pair peserta didik mengerjakan soal-soal di LKPD secara berpasangan. Untuk tahap Think peserta didik akan mengerjakan soal secara individu dan guru berkeliling di dalam kelas untuk memperhatikan tingkat kemampuan peserta didik dalam mengerjakan soal. Setelah tahap Think selesai, peserta didik berdiskusi secara berpasangan (Pair). Setiap pasangan berdiskusi tentang penyelesiaan soal yang ada di LKPD, guru memperhatikan keseriusan peserta didik dalam berdiskusi. Pada tahap inilah guru melihat kemampuan pemahaman konsep siswa. Setelah tahap Pair, beberapa pasangan membagi hasil diskusinya didepan kelas yaitu tahap Share. Pada tahap ini peserta didik mendiskusikan penyelesaian soal dan menuntaskan jawaban dari LKPD serta menyepakati jawaban dari setiap soal.

Ayuningtyas (2015) menyatakan bahwa: (1) Prestasi belajar siswa dengan model pembelajaran kooperatif tipe think-pair-share memberikan prestasi belajar yang lebih baik daripada model pembelajaran langsung. (2) Siswa yang kemandirian belajarnya tinggi mempunyai prestasi belajar yang lebih baik daripada siswa dengan kemandirian belajar sedang dan rendah, sedangkan siswa yang kemandirian belajarnya sedang mempunyai prestasi belajar yang sama dengan siswa dengan kemandirian belajar rendah. (3) Pada siswa yang mempunyai kemandirian belajar tinggi, metode think-pair-share memberikan prestasi belajar yanglebih baik daripada model pembelajaran langsung. Selain itu, pada siswa dengan kemandirian belajar sedang dan rendah metode think-pair-share dan pembelajaran langsung memberikan prestasi belajar yang sama. Lebih lanjut Ayuningtyas menyarankan bahwa guru yang akan menerapkan metode think-pair-share ini hendaknya pembentukan kelompok belajar lebih memperhatikan heterogenitas siswa dalam suatu kelas, termasuk kemandirian belajar siswa. Peneliti lain juga dapat melakukan penelitian dengan inovasi baru lainnya dan dengan memperhatikan variabel-variabel bebas lainnya yang mempengaruhi prestasi belajar siswa.

Respon siswa pada seluruh aspek baik minat maupun motivasi siswa yang meliputi: attention, relevance, confidence, dan satisfaction memiliki kategori baik, ini mengindikasikan bahwa siswa sudah memberikan perhatian positif dan baik terhadap pembelajaran model kooperatif dengan metode think-pair-share yang telah dilaksanakan, siswa merasakan keterkaitan materi yang disampaikan dengan materi terdahulu dan kehidupan sehari-hari, siswa sudah yakin akan kemampuan sendiri (percaya diri) dan dalam kategori baik, kepuasan siswa setelah mengikuti proses pembelajaran kooperatif dengan metode think-pair-share juga 
telah dalam kategori baik. Tiga aspek keterampilan sosial siswa yang diamati yakni mendengarkan secara aktif, mengajukan pertanyaan dan mengajukan pendapat juga mengalami peningkatan dalam setiap pertemuan. Hasil belajar siswa melalui penerapan model pembelajaran kooperatif dengan metode think-pair-share pun mengalami peningkatan yang signifikan (Sanjaya, dkk, 2013).

Mutia, dkk, (2020) meyatakan bahwa kelebihan pembelajaran kooperatif dengan metode think-pair-share (TPS) diantaranya adalah: 1) Memiliki prosedur yang ditetapkan secara ekplisit untuk memberi sisa waktu lebih banyak untuk berfikir, menjawab, dan saling membantu satu sama lain; 2) Memberdayakan kemampuan berfikir siswa; 3) Membiasakan siswa untuk lebih berani mengeluarkan pendapat. Lebih lanjut Mutia, dkk, menyatakan bahwa pembelajaran kooperatif dengan metode think-pair-share dapat meningkatkan hasil belajar siswa diantaranya disebabkan karena: 1) TPS memberikan kesempatan pada siswa untuk saling membantu dalam mengerjakan tugas yang diberikan oleh guru, 2) TPS menuntut siswa untuk berusaha sendiri dan bertanggung jawab atas jawabannya dan yang akan dilaporkan kepada kelompoknya, 3) TPS dapat meningkatkan rasa percaya diri siswa, 4) TPS memberi kesempatan kepada siswa untuk memikirkan jawaban dari permasalahan yang diberikan oleh guru sehingga pada saat diskusi kelompok tugas yang diberikan dapat diselesaikan dengan baik, 5) TPS dapat meningkatkan kemampuan siswa dalam mengingat suatu informasi, 6) Siswa menjadi lebih aktif dalam berfikir mengenai konsep dalam mata pelajaran, dan 7) Siswa lebih memahami konsep topik pembelajaran selama diskusi.

Selain dapat meningkatkan keterampilan berpikir kritis mahasiswa, penerapan metode think-pair-share sebagai bentuk pembelajaran brainstorming dapat meningkatkan keterampilan menulis artikel ilmiah mahasiswa. Dengan kata lain, melalui pembiasaan melakukan analisis artikel, mahasiswa akan terlatih dalam menulis artikel dan mahasiswa dapat mengembangkan kemampuan berpikir kritis mereka (Hariyadi, dkk, 2019).

Pembelajaran dengan melakukan analisis artikel ilmiah dapat melatih kemampuan mahasiswa untuk melakukan proses berpikir ilmiah. Artikel ilmiah merupakan salah satu bentuk penyajian suatu ilmu pengetahuan yang didapatkan melalui proses penelitian berdasarkan metode ilmiah. Dengan demikian, melalui kegiatan menganalisis artikel ilmiah akan membuat mahasiswa berlatih memahami proses berpikir ilmiah seperti halnya yang dilakukan oleh para ilmuwan. Semakin banyak berlatih untuk berpikir ilmiah melalui analisis artikel ilmiah membantu mahasiswa untuk meningkatkan kemampuan berpikir ilmiah serta dapat menambah pengetahuan mereka sesuai dengan perkembangan ilmu pengetahuan tersebut, sehingga memiliki kesiapan untuk mengembangkan dan mengamalkan ilmu pengetahuan yang dimiliki (Rahayu, dkk, 2013). Tujuan penelitian ini adalah untuk mendeskripsikan penerapan metode think-pair-share dengan analisis artikel sehingga dapat meningkatkan keterampilan berpikir tingkat tinggi mahasiswa.

\section{METODE}

Jenis penelitian ini termasuk ke dalam penelitian pra-eksperimental. Subjek penelitian meliputi mahasiswa yang mengikuti mata kuliah Strategi Pembelajaran Fisika, tahun akademik 2020/2021, pada salah satu Universitas di Mataram, sebanyak 27 orang mahasiswa. Desain penelitian yang digunakan dalam penelitian ini adalah One Group Pre-test dan Posttest Design (Arikunto, 2006). Instrumen penelitian yang digunakan adalah tes keterampilan berpikir tingkat tinggi (Higher Order Thinking Skills/HOTS). Tingkat keterampilan berpikir tingkat tinggi mahasiswa dihitung dalam bentuk persentase, dengan 5 kategori seperti yang ditunjukkan pada Tabel 1. 
Tabel 1. Pedoman Penilaian HOTS

\begin{tabular}{lll}
\hline Tingkat penguasaan $(\%)$ & Nilai Huruf & Kategori \\
\hline $86-100$ & A & Sangat Baik \\
$76-85$ & B & Baik \\
$60-75$ & C & Cukup \\
$55-59$ & D & Kurang \\
$\leq 54$ & E & Kurang Sekali \\
\hline
\end{tabular}

Sumber: Purwanto (2004)

Peningkatan skor dihitung menggunakan $N$-gain (Hake, 1999) dengan menggunakan rumus:

$$
\mathrm{N}-\text { gain }=\frac{\mathrm{S}_{\text {post }}-\mathrm{S}_{\text {pre }}}{\mathrm{S}_{\max }-\mathrm{S}_{\text {pre }}} \times 100 \%
$$

Kriteria perolehan $N$-gain terbagi ke dalam 3 kriteria seperti ditunjukkan pada Tabel 2. Tabel 2. Kriteria Perolehan $N$-gain

\begin{tabular}{lll}
\hline No. & Interval $(\%)$ & Kriteria \\
\hline 1 & $\mathrm{~g}>70$ & Tinggi \\
2 & $30 \leq \mathrm{g} \leq 70$ & Sedang \\
3 & $\mathrm{~g}<30$ & Rendah \\
\hline
\end{tabular}

\section{HASIL DAN PEMBAHASAN}

Hasil penelitian berupa data kategori keterampilan berpikir tingkat tinggi (HOTS) dan data kriteria peningkatan skor HOTS dalam bentuk $N$-gain dapat dilihat pada Tabel 3.

Tabel 3. Kategori HOTS dan Kriteria $N$-gain

\begin{tabular}{|c|c|c|c|c|c|c|c|c|}
\hline Nomor Urut & Pre-Tes & & & Post-Te & & & N-gai & \\
\hline Mahasiswa & $\begin{array}{l}\text { Nilai } \\
\text { HOTS }\end{array}$ & $\begin{array}{l}\text { Nilai } \\
\text { Huruf }\end{array}$ & Kategori & $\begin{array}{l}\text { Nilai } \\
\text { HOTS }\end{array}$ & $\begin{array}{l}\text { Nilai } \\
\text { Huruf }\end{array}$ & Kategori & Nilai & Kriteria \\
\hline NUM 1 & 45 & $\mathrm{E}$ & $\begin{array}{l}\text { Kurang } \\
\text { Sekali }\end{array}$ & 80 & B & Baik & 64 & Sedang \\
\hline NUM 2 & 40 & $\mathrm{E}$ & $\begin{array}{l}\text { Kurang } \\
\text { Sekali }\end{array}$ & 80 & B & Baik & 67 & Sedang \\
\hline NUM 3 & 40 & $\mathrm{E}$ & $\begin{array}{l}\text { Kurang } \\
\text { Sekali }\end{array}$ & 80 & B & Baik & 67 & Sedang \\
\hline NUM 4 & 50 & $\mathrm{E}$ & $\begin{array}{l}\text { Kurang } \\
\text { Sekali }\end{array}$ & 90 & A & $\begin{array}{l}\text { Sangat } \\
\text { Baik }\end{array}$ & 80 & Tinggi \\
\hline NUM 5 & 55 & $\mathrm{D}$ & Kurang & 90 & A & $\begin{array}{l}\text { Sangat } \\
\text { Baik }\end{array}$ & 78 & Tinggi \\
\hline NUM 6 & 45 & $\mathrm{E}$ & $\begin{array}{l}\text { Kurang } \\
\text { Sekali }\end{array}$ & 75 & $\mathrm{C}$ & Cukup & 55 & Sedang \\
\hline NUM 7 & 40 & $\mathrm{E}$ & $\begin{array}{l}\text { Kurang } \\
\text { Sekali }\end{array}$ & 75 & $\mathrm{C}$ & Cukup & 58 & Sedang \\
\hline NUM 8 & 50 & $\mathrm{E}$ & $\begin{array}{l}\text { Kurang } \\
\text { Sekali }\end{array}$ & 80 & B & Baik & 60 & Sedang \\
\hline NUM 9 & 55 & $\mathrm{D}$ & Kurang & 90 & A & $\begin{array}{l}\text { Sangat } \\
\text { Baik }\end{array}$ & 78 & Tinggi \\
\hline NUM 10 & 55 & $\mathrm{D}$ & Kurang & 90 & A & $\begin{array}{l}\text { Sangat } \\
\text { Baik }\end{array}$ & 78 & Tinggi \\
\hline
\end{tabular}




\begin{tabular}{|c|c|c|c|c|c|c|c|c|}
\hline NUM 11 & 55 & D & Kurang & 90 & A & $\begin{array}{l}\text { Sangat } \\
\text { Baik }\end{array}$ & 78 & Tinggi \\
\hline NUM 12 & 40 & $\mathrm{E}$ & $\begin{array}{l}\text { Kurang } \\
\text { Sekali }\end{array}$ & 75 & $\mathrm{C}$ & Cukup & 58 & Sedang \\
\hline NUM 13 & 55 & $\mathrm{D}$ & Kurang & 95 & A & $\begin{array}{l}\text { Sangat } \\
\text { Baik }\end{array}$ & 89 & Tinggi \\
\hline NUM 14 & 55 & $\mathrm{D}$ & Kurang & 90 & A & $\begin{array}{l}\text { Sangat } \\
\text { Baik }\end{array}$ & 78 & Tinggi \\
\hline NUM 15 & 40 & $\mathrm{E}$ & $\begin{array}{l}\text { Kurang } \\
\text { Sekali }\end{array}$ & 75 & $\mathrm{C}$ & Cukup & 58 & Sedang \\
\hline NUM 16 & 45 & $\mathrm{E}$ & $\begin{array}{l}\text { Kurang } \\
\text { Sekali }\end{array}$ & 75 & $\mathrm{C}$ & Cukup & 55 & Sedang \\
\hline NUM 17 & 40 & $\mathrm{E}$ & $\begin{array}{l}\text { Kurang } \\
\text { Sekali }\end{array}$ & 75 & $\mathrm{C}$ & Cukup & 58 & Sedang \\
\hline NUM 18 & 55 & $\mathrm{D}$ & Kurang & 90 & A & $\begin{array}{l}\text { Sangat } \\
\text { Baik }\end{array}$ & 78 & Tinggi \\
\hline NUM 19 & 55 & $\mathrm{D}$ & Kurang & 90 & A & $\begin{array}{l}\text { Sangat } \\
\text { Baik }\end{array}$ & 78 & Tinggi \\
\hline NUM 20 & 55 & $\mathrm{D}$ & Kurang & 90 & A & $\begin{array}{l}\text { Sangat } \\
\text { Baik }\end{array}$ & 78 & Tinggi \\
\hline NUM 21 & 55 & D & Kurang & 90 & A & $\begin{array}{l}\text { Sangat } \\
\text { Baik }\end{array}$ & 78 & Tinggi \\
\hline NUM 22 & 50 & $\mathrm{E}$ & $\begin{array}{l}\text { Kurang } \\
\text { Sekali }\end{array}$ & 85 & B & Baik & 70 & Sedang \\
\hline NUM 23 & 55 & D & Kurang & 85 & B & Baik & 67 & Sedang \\
\hline NUM 24 & 55 & $\mathrm{D}$ & $\begin{array}{l}\text { Kurang } \\
\text { Sekali }\end{array}$ & 90 & A & $\begin{array}{l}\text { Sangat } \\
\text { Baik }\end{array}$ & 78 & Tinggi \\
\hline NUM 25 & 50 & $\mathrm{E}$ & $\begin{array}{l}\text { Kurang } \\
\text { Sekali }\end{array}$ & 80 & B & Baik & 60 & Sedang \\
\hline NUM 26 & 35 & $\mathrm{E}$ & $\begin{array}{l}\text { Kurang } \\
\text { Sekali }\end{array}$ & 70 & $\mathrm{C}$ & Cukup & 54 & Sedang \\
\hline NUM 27 & 45 & $\mathrm{E}$ & $\begin{array}{l}\text { Kurang } \\
\text { Sekali }\end{array}$ & 75 & $\mathrm{C}$ & Cukup & 55 & Sedang \\
\hline Rerata & 49 & $\mathbf{E}$ & $\begin{array}{l}\text { kurang } \\
\text { Sekali }\end{array}$ & 83 & B & Baik & 68 & Sedang \\
\hline
\end{tabular}

Berdasarkan Tabel 3 diperoleh informasi bahwa nilai rerata HOTS mahasiswa sebelum perlakuan pembelajaran menggunakan metode think-pair-share adalah sebesar 49 yang berada pada kategori Kurang Sekali, nilai tersebut meningkat setelah pembelajaran menggunakan metode think-pair-share menjadi 83 yang berada pada kategori Baik. Nilai Ngain diperoleh sebesar 68 dengan kriteria Sedang.

Hasil penelitian tentang HOTS dan peningkatan skor HOTS dalam bentuk diagram dapat ditunjukkan Gambar 1. 


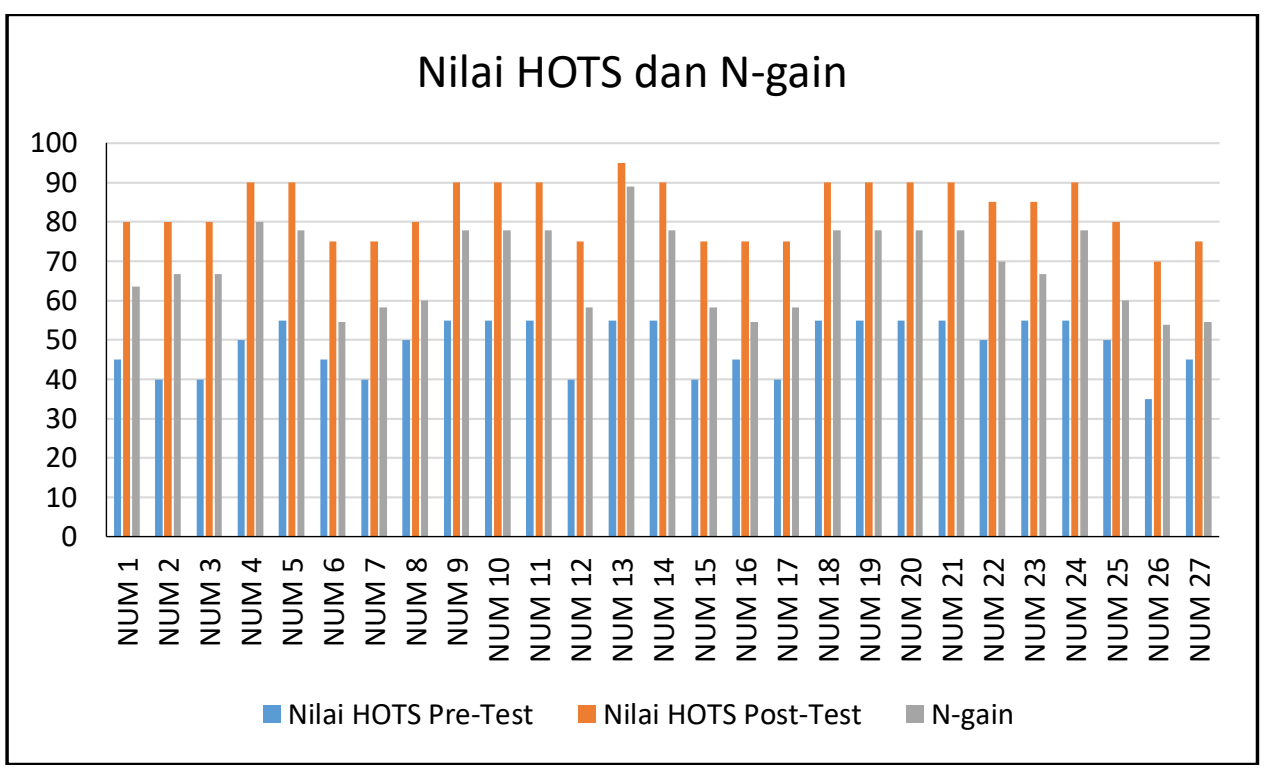

Gambar 1. Nilai HOTS dan N-gain

Penerapan model pembelajaran kooperatif dengan metode think-pair-share berbantuan media pembelajaran (lingkungan) berpengaruh terhadap penguasaan kompetensi pengetahuan siswa (Raharja, dkk, 2019). Media pembelajaran yang dapat digunakan (selain lingkungan) dalam metode think-pair-share adalah media sosial seperti Google Meet, WhatsApp Messenger (WA), dan MOODLE. Pada kegiatan awal dosen memberikan penjelasan informasi tentang materi melalui Google Meet, setelah itu dosen memberikan tugas untuk mencari artikel di internet sesuai dengan materi yang sedang dibahas. Selanjutnya, mahasiswa diberikan kesempatan untuk berpikir (think) secara mandiri tentang informasi yang diberikan oleh dosen, serta melakukan analisis terhadap artikel yang sudah diunduh. Kegiatan mahasiswa pada tahap pair (berpasangan) dapat dilakukan dengan cara berdiskusi melalui aplikasi WA. Menurut https://id.wikipedia.org/wiki/WhatsApp, WhatsApp Messenger (WA) adalah aplikasi pesan untuk ponsel cerdas. WA merupakan aplikasi pesan lintas platform yang memungkinkan kita bertukar pesan tanpa pulsa, karena $W A$ menggunakan paket data internet. Aplikasi WA menggunakan koneksi internet 3G, 4G atau WiFi untuk komunikasi data. Kegiatan berbagi (share) dilakukan dengan presentasi mahasiswa bersama pasangan melalui menu "Forum Diskusi" di https://daring.unram.ac.id/ yang disediakan oleh dosen. Pembelajaran daring pada tahap share ini memanfaatkan MOODLE (Modular ObjectOriented Dynamic Learning Environment). Menurut https://id.wikipedia.org/wiki/Moodle, MOODLE adalah paket perangkat lunak yang diproduksi untuk kegiatan belajar berbasis internet dan situs web yang menggunakan prinsip social constructionist pedagogy. MOODLE merupakan salah satu aplikasi dari konsep dan mekanisme belajar mengajar yang memanfaatkan teknologi informasi, yang dikenal dengan konsep pembelajaran elektronik atau e-learning. Di dunia e-learning Indonesia, MOODLE lebih dikenal fungsinya sebagai Course Management System atau Learning Management System (LMS).

Materi yang dibahas dalam penelitian selama 6 kali pertemuan ini terdiri atas 3 topik meliputi model pembelajaran kooperatif, model pembelajaran berbasis inkuiri, dan model pembelajaran berbasis masalah. Aktivitas pada menu forum "DISKUSI SESI 1" dilakukan pada pertemuan pertama, yaitu dosen memberikan tugas berupa analisis artikel sesuai dengan topik yang dibahas, sedangkan aktivitas pada menu forum "DISKUSI SESI 2" dilakukan pada pertemuan kedua, yaitu dosen memberikan tugas berupa analisis RPP untuk memantapkan materi. Bentuk aktivitas pembelajaran dalam https://daring.unram.ac.id/ untuk penelitian ini dapat dilihat pada Gambar 2. 
7. Course: STRATEg PEMBELA $x+$

$\leftarrow \rightarrow C \backsim$ daring.unram.ac.id/course/view.php?id=5050

\begin{tabular}{|l|}
\hline P STRATEGI \\
PEMBELAJARAN FISIKA \\
2021
\end{tabular}

Pertemuan 5 Tanggal 15 Maret 2021

$$
\text { I. At }
$$

DAFTAR HADIR

(N) Materi Model Pembelajaran Inkuiri

绕 DISKUSI SESI 1: MODEL. PEMBELAJARAN BERBASIS INKUIRI

Kegiatan pemantapan materi:

Carilah 1 artikel dalam jurnal yang membahas tema model pembelajaran inkuiri.

Buatlah analisis tentang artikel tersebut, terutama analisis tentang model pembelajarannya (definisi, ciri-ciri, sintaks, kelebihan, kekurangan manfaat, dII)!

\section{Pertemuan 6 Tanggal 22 Maret 2021}

\section{Attendance}

DAFTAR HADIR

DISKUSI SESI 2: MODEL PEMBELAJARAN BERBASIS INKUIRI

Kegiatan pemantapan materi

PETUNJUK: Carilah contoh RPP yang menggunakan model pembelajaran INKUIRI. Berdasarkan contoh RPP tersebut, tuliskan mater pembelajaran, tujuan pembelajaran, dan langkah-langkah pembelajaran menggunakan model INKUIRI! Berikan tanggapan terhadap tujuan, materi, dan langkah-langkah pembelajaran berdasarkan konsep model pembelajaran INKUIRI yang sudah dipelajari
Materi Model Pembelajaran Inkuiri

Gambar 2. Aktivitas pembelajaran dalam https://daring.unram.ac.id/

Hasil analisis artikel yang dilakukan mahasiswa pada penelitian ini dapat dilihat pada Gambar 3 .

Gambar 3. Hasil analisis artikel

Penerapan metode diskusi-presentasi (seperti halnya dalam metode think-pair-share) yang dipadu dengan analisis kritis artikel dapat meningkatkan pemahaman konsep, kemampuan berpikir kritis, dan komunikasi mahasiswa (Mitasari \& Prasetiyo, 2016). Berpikir kritis dan kemampuan komunikasi merupakan kompetensi yang harus dimiliki 
mahasiswa untuk menghadapi persaingan global pada abad 21 ini. Kompetensi tersebut merupakan bagian dari Higher Order Thinking Skills (HOTS) yang dapat digunakan dalam meningkatkan kemampuan kognitif mahasiswa. Mahasiswa yang memiliki HOTS yang tinggi dapat menjawab baik dalam menggunakan pendapat, ide atau gagasan yang relevan dengan topik bahasan dan mahasiswa menjawab sangat baik dalam memberikan alternatif solusi terhadap permasalahan yang ditemukan pada topik bahasan (Selegi, 2019).

Pelaksanaan pembelajaran dengan menggunakan model pembelajaran Think, Pair, and Share tidak hanya berpusat kepada guru (Teacher Center), tetapi lebih melibatkan siswa (Student Center), maka dengan penerapan model Think, Pair, and Share ini siswa akan lebih aktif dan dapat bekerja sama bersama teman kelompoknya, sehingga hal tersebut dapat meningkatkan hasil belajar siswa (Dinaqi, dkk, 2019). Penerapan pembelajaran kooperatif (termasuk dengan metode think-pair-share) secara umum dapat meningkatkan keterampilan berpikir tingkat tinggi dan hasil belajar kognitif siswa. Keterampilan berpikir tingkat tinggi siswa dapat diukur berdasarkan kemampuan siswa dalam menyelesaikan/ memecahkan lembar kegiatan siswa yang memuat kriteria terpenuhinya keterampilan berpikir tingkat tinggi siswa. Hasil belajar kognitif siswa dapat diperoleh dari hasil belajar produk dan hasil belajar proses selama pembelajaran menggunakan model kooperatif (Ita, 2018).

Menurut Ekawati (2016), Meiharty (2018), Kurniawan, dkk (2020), Syahwi, dkk (2020), model pembelajaran Kooperatif dengan metode Think Pair Share (TPS) dapat meningkatkan hasil belajar siswa. Model pembelajaran tersebut dapat meningkatkan prestasi belajar siswa (Ilham \& Budhi, 2018), partisipasi siswa (Perawati, dkk, 2020), dan minat belajar siswa (Rismaningtyas, dkk, 2019). Pembelajaran kooperatif dengan metode tipe thinkpair-share dapat meningkatkan keterampilan berpikir tingkat tinggi, termasuk keterampilan berpikir kritis. Indikator keterampilan berpikir kritis yang dapat dilatihkan selama pembelajaran dengan metode think-pair-share adalah: melakukan induksi, merumuskan masalah, melakukan deduksi, mengajukan argument, dan membuat evaluasi (Fitrihidajati, dkk, 2010).

Penerapan model pembelajaran kooperatif dengan metode think-pair-share dapat meningkatkan kemampuan berpikir kreatif matematis siswa (Florentina \& Leonard, 2017). Model ini juga dapat meningkatkan kemampuan pemecahan masalah matematis dengan kualitas peningkatan berada pada interpretasi sedang. Untuk menerapkan metode think-pairshare di kelas diperlukan perincian kegiatan pembelajaran, persiapan lembar kerja siswa, dan pembuatan instrumen yang baik (Latifah \& Luritawaty, 2020). Penerapan model pembelajaran tersebut dapat meningkatkan pemahaman siswa tentang konsep yang terdapat pada mata pelajaran. Dalam implementasi metode think-pair-share di kelas, guru dapat memberikan kebebasan kepada siswa untuk mengelolan informasi yang telah disampaikan dan sumber-sumber belajar yang dapat digunakan. Siswa menjadi lebih antusias dalam pembelajaran, yang ditunjukkan dengan semangat siswa dalam belajar, respon siswa terhadap mata pelajaran, jumlah siswa yang bertanya dan menanggapi penjelasan guru menjadi lebih banyak, dan siswa dapat membuat rangkuman materi dengan baik (Mukhoyyaroh \& Jazil, 2013). Selain model pembelajaran kooperatif dengan metode TPS, model lain yang dapat meningkatkan keterampilan berpikir tingkat tinggi adalah model STEM seperti yang dikembangkan oleh Hikmawati, dkk. (2020), dan model pembelajaran inkuiri yang dilakukan oleh Yuliana, dkk. (2020).

\section{KESIMPULAN}

Kesimpulan dari penelitian ini adalah metode think-pair-share sebagai salah satu metode dalam model pembelajaran kooperatif dapat menjadi alternatif bagi dosen untuk meningkatkan keterampilan berpikir tingkat tinggi (Higher Order Thinking Skills/HOTS) mahasiswa pada mata kuliah Strategi Pembelajaran Fisika. 


\section{SARAN}

Saran yang dapat penulis sampaikan yaitu sebaiknya dilakukan penelitian dalam bentuk true eksperiment dengan menggunakan kelas eksperimen dan kelas kontrol serta subjek penelitian yang lebih banyak. Peneliti lain juga dapat menguji penerapan metode think-pair-share ini pada mata kuliah lainnya dengan variable selain keterampilan berpikir tingkat tinggi. Di samping itu pula, peneliti lain dapat membandingkan metode think-pair-share dengan metode lainnya yang ada pada model pembelajaran kooperatif.

\section{DAFTAR PUSTAKA}

Arikunto, Suharsimi. 2006. Prosedur Penelitian: Suatu Pendekatan Praktik. Jakarta: Rineka Cipta.

Astriani, N. (2017). Upaya Meningkatkan Kemampuan Berpikir Kritis Siswa Dalam Pembelajaran Matematika Melalui Model Pembelajaran Kooperatif Tipe Think Pair Share (TPS) Kelas VII C SMP Negeri 11 Yogyakarta. Fakultas Keguruan dan Ilmu Pendidikan Universitas PGRI Yogyakarta.

Ayuningtyas, A., D. (2015). Eksperimentasi Model Pembelajaran Kooperatif Tipe Think Pair Share (TPS) Ditinjau Dari Kemandirian Belajar Siswa Kelas VIII SMP Negeri Di Kota Yogyakarta. Jurnal Ilmiah Pendidikan Matematika, Vol 3 No. 2, 452-466.

Dinaqi, A., A., N., Rakhmat, C., \& Nugraha, F. (2019). Penerapan Model Pembelajaran Think, Pair, and Share Terhadap Peningkatan Hasil Belajar Siswa Pada Pembelajaran IPS di Kelas V SD Negeri I Bojonggambir. 4th National Seminar on Guidance and Counseling (SNBK 2019) and Workshop on Pedagogical Theory and Practice (WTPP 2019). SHEs: Conference Series, 2 (2), 80 - 87.

Ekawati, H. (2016). Perbedaan Penerapan Model Pembelajaran Pembelajaran Kooperatif Tipe Think-Pair-Share Dan Pembelajaran Konvensional Pada Kelas VII SMP Negeri 10 Samarinda. Jurnal Pendas Mahakam,Vol. 1 (1), 54-64.

Fitrihidajati, H., Indah, N., K., \& Susantini, E. (2010). Penerapan Perangkat Pembelajaran Biologi Berbasis Kooperatif Tipe Think Pair Share (TPS) Untuk Meningkatkan Keterampilan Berpikir Kritis Di SMA Sejahtera Surabaya. Seminar Nasional Pendidikan Biologi FKIP UNS 2010.

Florentina, N. \& Leonard. (2017). Pengaruh Model Pembelajaran Kooperatif Terhadap Kemampuan Berpikir Kreatif Matematis Siswa. Jurnal Formatif, 7 (2), 96-106.

Hake, R. 1999. Analyzing Change/ Gain Score. Indiana: Indiana University.

Hariyadi, Alimin, A., A. \& Eti Ramaniyar, E. (2019). Pengaruh Metode Pembelajaran Brainstorming Terhadap Keterampilan Menulis Artikel Ilmiah. Jurnal Pendidikan Bahasa, Vol. 8, No. 2, 330-341.

Hikmawati, H., Sahidu, C., Kosim, K., Sutrio, S., Gunawan, G. (2020). Tahap Define dalam Pengembangan Perangkat Pembelajaran Berbasis STEM untuk Meningkatkan Keterampilan Berpikir Tingkat Tinggi Mahasiswa. Kappa Journal, 4(2), 149-157.

Ilham \& Budhi, W. (2018). Pengaruh Model Pembelajaran Kooperatif Tipe Think Pair Share Terhadap Prestasi Belajar Fisika Pokok Bahasan Getaran Dan Gelombang. Jurnal Ilmiah Pendidikan Fisika-COMPTON, Volume 5, Nomor 1, 62-69.

Ita. (2018). Keterampilan Berpikir Tingkat Tinggi dan Hasil Belajar Kognitif Siswa melalui Pembelajaran Kooperatif Berbasis Inkuiri. (Student's High Order Thinking Skill and Their Cognitive Achievement Through Cooperative Learning Based on Inquiry). BIOEDUKASI: Jurnal Pendidikan Biologi, Volume 11, Nomor 1, 23-28.

Kurniawan, D, Wahyuningsih, T., \& Sari, D., N. (2020). Pengaruh Model Pembelajaran Kooperatif Tipe Think Pair Share dengan Menggunakan Power Point Terhadap Hasil Belajar Matematika. Jurnal Pendidikan Matematika (Kudus), Volume 3, Nomor 1, 59-72. DOI: http://dx.doi.org/10.21043/jpm.v3i1.7149 
Latifah, S., S. \& Luritawaty, I., P. (2020). Think Pair Share sebagai Model Pembelajaran Kooperatif untuk Peningkatan Kemampuan Pemecahan Masalah Matematis. (Think Pair Share Type Cooperative Learning Model to improve Mathematical Problem Solving Ability). Mosharafa: Jurnal Pendidikan Matematika, Volume 9, Nomor 1, 35-46.

Meiharty, F. (2018). Penerapan Model Pembelajaran Kooperatif Tipe Think Pair Share Untuk Memperbaiki Proses Pembelajaran Dan Meningkatkan Hasil Belajar IPS Siswa Kelas V SD Negeri 21 Balai Makam Kecamatan Mandau. Primary: Jurnal Pendidikan Guru Sekolah Dasar Fakultas Keguruan dan Ilmu Pendidikan Universitas Riau, Volume 7, Nomor 2, 312-320.

Mitasari, Z \& Prasetiyo, N., A. (2016). Penerapan Metode Diskusi-Presentasi Dipadu Analisis Kritis Artikel melalui Lesson Study untuk Meningkatkan Pemahaman Konsep, Kemampuan Berpikir Kritis, dan Komunikasi. Jurnal BIOEDUKATIKA, Vol. 4 No. 1, 1114.

Mukhoyyaroh, S. \& Jazil, S. (2013). Pengaruh Model Pembelajaran Kooperatif Tipe TPS (Think Pais Share) Terhadap Pemahaman Siswa Pada Mata Pelajaran Fiqih Kelas VII MTs Al Irsyadiyah Dermolemahbang Sarirejo Lamongan. Jurnal Pendidikan Agama Islam, Vol 1, No 1, 22-24.

Mutia, T., Agustina, S., Suroso, \& Akhmad, R. (2020). Pengaruh Pembelajaran Kooperatif Model Think Pair Share (TPS) Terhadap Hasil Belajar Geografi. Geodika: Jurnal Kajian Ilmu dan Pendidikan Geografi, Volume 4 Nomor 2, 210-219. DOI: 10.29408/geodika.v4i2.2869.

Nikmah, F., L. (2018). Penerapan Strategi Pembelajaran Kooperatif Think Pair Share (TPS) Untuk Meningkatkan Kemampuan Berpikir Kritis Siswa Kelas X MIPA 4 MAN 1 Kota Kediri Pada Materi Vertebrata. Artikel Skripsi Universitas Nusantara PGRI Kediri.

Perawati, Sukendro, \& Sulistyo, U. (2020). Penerapan Model Kooperatif Tipe Think Pair Share untuk Meningkatkan Partisipasi Siswa pada Materi Pembelajaran IPA di Kelas VI SDN 113 Kota Jambi. JURNAL GENTALA PENDIDIKAN DASAR, Vol.5 No. I, 42-61. DOI: https://doi.org/10.22437/gentala.v5i1.9425

Purwantika, F., Yensy, N., A., \& Agustinsa, R. (2020). Pebedaan Proses Belajar Matematika Siswa Yang Menggunakan Model Pembelajaran Kooperatif Tipe Think Pair Share (TPS) Dengan Pembelajaran Ekspositori. Jurnal Penelitian Pembelajaran Matematika Sekolah (JP2MS), Volume 4, No.1, 1-8. DOI: https://doi.org/10.33369/jp2ms.4.1.1-8

Purwanto, M., N. (2004). Prinsip-Prinsip dan Teknik Evaluasi Pengajaran. Bandung: Remaja Rosdakarya.

Rahayu, P., Ulfah, M., Dewi, L., R. (2013). Pembelajaran Analisis Artikel Ilmiah Untuk Meningkatkan Kemampuan Berpikir Ilmiah. Seminar Nasional X Pendidikan Biologi FKIP UNS (SEMBIO). Surakarta: Universitas Sebelas Maret.

Raharja, N., M., G., Kristiantari, M., G., R., \& Manuaba, I., B., S. (2019). Model Pembelajaran Think Pair Share Berpengaruh Terhadap Kompetensi Pengetahuan IPA Siswa Kelas V SD. Jurnal Pendidikan dan Pembelajaan IPA Indonesia, Volume 9 Nomor 3, 95-103.

Rismaningtyas, R., Y., Sujatmiko, P., Ira Kurniawati, I. (2019). Eksperimentasi Model Pembelajaran Kooperatif Tipe Think Pair Share (TPS) pada Materi Pokok Trigonometri Ditinjau dari Minat Belajar Matematika Siswa Kelas X Semester Ii Sma Negeri 6 Surakarta Tahun Pelajaran 2018/2019. Jurnal Pendidikan Matematika dan Matematika (JPMM) Solusi, Vol. III 4, 370-382.

Sanjaya, B., Wati, M., \& An'nur, S. (2013). Meningkatkan Hasil Belajar Siswa Melalui Penerapan Pembelajaran Kooperatif Tipe Think Pair-Share (TPS). Berkala Ilmiah Pendidikan Fisika, Vol. 1 no, 3, 278-289. 
Selegi, S., F. (2019). Analisis Kemampuan Higher Order Thinking Skill (HOTS) Melalui Creative Problem Solving (CPS) Untuk Meningkatkan Kemampuan Kognitif Mahasiswa. Jurnal Swarnabhumi, Vol. 4, No.1, 24-34.

Syahwi, S., A., Muhiddin, N., H., \& Ramlawati. (2020). Pengaruh Model Pembelajaran Kooperatif Tipe Think Pair Share (TPS) Terintegrasi Praktikum Terhadap Hasil Belajar IPA. Jurnal IPA Terpadu, 4 (1), 1-11.

Yuliana, Y., Hikmawati, H., \& Wahyudi, W. (2020). Pengaruh Model Pembelajaran Inkuiri Terbimbing Berbantuan Peta Konsep Terhadap Kemampuan Berpikir Kritis Peserta Didik. Kappa Journal, 4(1), 85-92. 